\title{
Katarak Pediatrik: Profil Klinik dan Faktor Determinan Hasil Terapi
}

\section{Pediatric Cataract: Clinical Profile and Outcomes Determinant}

\author{
Lely Retno W, Kristina Radika HK \\ Laboratorium Ilmu Kesehatan Mata Rumah Sakit Umum Dr. Saiful Anwar Malang
}

\begin{abstract}
ABSTRAK
Katarak pediatrik merupakan salah satu penyebab utama kebutaan dan low vision pada anak, terutama di negara-negara berkembang. Studi data sekunder berbasis rumah saki dilakukan selama 4 tahun, sejak Desember 2006 sampai Desember 2010. Pengumpulan data meliputi jenis kelamin, usia, usia onset, faktor penyebab, bilateralitas, visus pre dan post operasi, jenis operasi, komplikasi pre dan post operasi, dan follow up dari 58 mata yang berasal dari 43 penderita. Data dianalisa secara deskriptif serta dilakukan analisis korelasi antara usia operasi dan jenis operasi dengan visus hasil operasi. Penderita berjenis kelamin laki-laki lebih banyak didapatkan daripada perempuan $(67,4 \%)$, dengan penyebab terbanyak katarak pediatrik adalah non traumatik $(67,4 \%)$ yang didapatkan sejak lahir $(51,6 \%)$. Pada kelompok traumatik katarak, usia penderita dan usia operasi terbanyak adalah 6-10 tahun (73,3\%), sedangkan kelompok non traumatik adalah 1-6 $(38,7 \%)$. Jenis operasi yang terbanyak dilakukan adalah Extra Capsular Cataract Extraction+Intraocular Lens+iridektomi perifer (31\%). Komplikasi nystagmus adalah yang terbanyak didapatkan pada katarak non traumatik (34,9\%). Pada evaluasi post operasi, 10 dari 15 penderita (66,7\%) pada kelompok traumatik mencapai visus $>6 / 18$, sedangkan $30,2 \%$ penderita katarak non traumatik mendapatkan visus 1/60-3/60. Pada penelitian ini didapatkan korelasi kuat antara penatalaksanaan operasi yang tertunda dengan buruknya visus pasca operasi $(r=0,707 ; p=0,000)$ tetapi tidak didapatkan korelasi antara tipe operasi dengan angka kejadian Posterior Capsular Opacification $(r=0,053 ; p=0,691)$. Dapat disimpulkan katarak non traumatik adalah penyebab utama katarak pediatrik, dengan sebagian besar kasus terjadi sejak lahir. Visus post operasi pada mayoritas kasus katarak non traumatik masih tergolong dalam low vision akibat keterlambatan penatalaksanaan operasi.
\end{abstract}

Kata Kunci: Katarak non traumatik, katarak pediatrik, katarak traumatik, visus

\begin{abstract}
Pediatric cataract is one of the important causes of low vision and blindness in children. This study aimed to describe the clinical characteristics and outcome of pediatric cataract. A retrospective-descriptive study was conducted over a period of 4 years, from December 2006 to December 2011. Data on gender, age, age of onset, causative factor, bilaterality, visual acuity before and after surgery, type of surgery, complications found before and after surgery, and follow up from 58 eyes of 43 pediatric patients were collected. Male patients contributed a higher percentage than female (67,4\%). The most frequent cause of pediatric cataract was non traumatic $(67,4 \%)$ and mostly found since birth $(51,6 \%)$. The mostly affected range of age and age of surgery were between 6 to 10 years old for traumatic cataract (73,3\%), and between 1-6 years old for non traumatic cataract (38,7\%). Among many types of surgery, Extra Capsular Cataract Extraction+Intraocular Lens+peripheral iridectomy was the most commonly performed (31\%). Nystagmus had already happened in most of the observed eye in non traumatic patients (34,9\%). In post operative course, 10 out of 15 patients (66,7\%) in traumatic patients achieved good visual acuity; in the contrary, most of non traumatic patients still in the low vision state (30,2\%). In this study there was a strong correlation between delayed surgery and poor post operative visual acuity $(r=0,707 ; p=0,000)$ but there was no correlation between types of surgery and incidence of Posterior Capsular Opacification, with $r=0,053$; $p=0,691$. Non traumatic cataract was the leading cause of pediatric cataract, with most of the cases occurred since birth. Post operative visual acuity in majority of non traumatic cataract case was still classified as low vision due to delayed treatment.
\end{abstract}

Keywords: Non traumatic cataract, pediatric cataract, traumatic cataract, visus

Jurnal Kedokteran Brawijaya, Vol. 27 No. 3, Februari 2013 ; Korespondensi: Kristina Radika HK. Laboratorium IImu Kesehatan Mata Rumah Sakit Umum Dr. Saiful Anwar Malang, Jl. Jaksa Agung Suprapto No.2 Malang, Tel. (0341)341945 Email: heepz81@yahoo.com 


\section{PENDAHULUAN}

Katarak pediatrik adalah kekeruhan lensa yang terjadi pada anak-anak. Kekeruhan lensa ini dapat diketahui segera setelah bayi lahir, atau dapat terjadi selama masa perkembangan anak. Katarak pada anak dapat bersifat kongenital maupun dapatan (acquired). Katarak yang bersifat kongenital antara lain disebabkan oleh kelainan genetik, infeksi intrauterin, berkaitan dengan sindroma, ataupun idiopatik, sedangkan katarak yang bersifat dapatan disebabkan oleh kelainan metabolik dan trauma $(1,2)$.

Hingga saat ini, katarak pediatrik merupakan salah satu penyebab utama kebutaan dan low vision pada anak, terutama di negara-negara berkembang. Prevalensi kebutaan yang disebabkan oleh katarak adalah sekitar 1-4 per 10.000 anak di negara berkembang. Di negara maju, angka prevalensinya adalah 0,1-0,4 per 10.000 anak. Dengan prevalensi tersebut, diperkirakan sekitar 190.000 anak di seluruh dunia mengalami kebutaan akibat katarak (1-3).

Penyebab utama hilangnya penglihatan akibat katarak pada anak adalah ambliopia. Gangguan pembentukan bayangan di retina pada 1 atau kedua mata selama periode kritis dapat menyebabkan terjadinya ambliopia yang irreversibel. Meski demikian, penatalaksanaan katarak pediatrik masih merupakan tantangan. Tingginya tingkat kesulitan intraoperatif, kecenderungan beratnya inflamasi pasca operatif, perubahan status refraksi, dan resiko komplikasi pasca operatif masih menjadi halangan untuk mencapai tajam penglihatan yang baik $(1,4-8)$.

Latar belakang dilakukannya penelitian ini adalah untuk mengetahui gambaran karakteristik, penatalaksanaan, dan hasil operasi dari penderita katarak pediatrik yang datang ke poliklinik pediatri ophthalmologi RSU Dr. Saiful Anwar Malang dimulai Desember 2006 sampai Desember 2010, dan sebagai data dasar bagi penelitian lebih lanjut. Penelitian ini dilakukan untuk memberikan gambaran karakteristik penderita, penatalaksanaan dan hasil operasi katarak pediatrik di Rumah Sakit Umum Dr. Saiful Anwar Malang pada periode Desember 2006-Desember 2010.

\section{METODE}

Data diambil dari rekam medis penderita dengan diagnosa katarak pediatrik yang datang ke poliklinik mata bagian Pediatri Ophthalmologi RSU Dr. Saiful Anwar Malang, selama kurun waktu 4 tahun (periode Desember 2006 sampai Desember 2010). Semua penderita katarak pediatrik yang datang ke poliklinik mata bagian Pediatri Ophthalmologi RSU Dr. Saiful Anwar Malang selama periode bulan Desember 2006 sampai Desember 2010 untuk kemudian mendapatkan penatalaksanaan berupa operasi katarak, serta melakukan kunjungan ulang pasca dilakukannya operasi katarak. Pengambilan sampel secara konsekutif mendapatkan 108 penderita dengan diagnosa katarak pediatrik.

Pengambilan data meliputi usia penderita; usia onset; jenis kelamin; penyebab katarak; lateralitas; tajam penglihatan pre operasi; komplikasi atau penyulit pre operasi; tindakan operasi yang dilakukan; tajam penglihatan pasca operasi; komplikasi pasca operasi; dan lama follow up. Data yang telah terkumpul dianalisa secara deskriptif dan dilakukan analisa korelasi dengan uji non parametrik Spearman untuk melihat hubungan usia dan jenis operasi dengan hasil operasi.

\section{HASIL}

\section{Karakteristik Klinis dan Terapi Katarak Pediatrik}

Berdasarkan data rekam medis periode Desember 2006 sampai Desember 2010 didapatkan 108 penderita yang didiagnosa menderita katarak pediatrik, akan tetapi hanya sebanyak 46 penderita dengan 58 mata yang memenuhi kriteria inklusi. Dari 46 penderita yang didapatkan 31 penderita $(67,4 \%)$ berjenis kelamin laki-laki dan 15 penderita $(32,6 \%)$ berjenis kelamin perempuan. Penyebab katarak pada penelitian dibagi menjadi 2 kelompok yaitu traumatik dan non traumatik. Katarak pediatrik karena trauma didapatkan pada 15 penderita (32,6\%), sedangkan penyebab non traumatik didapatkan pada 31 penderita $(67,4 \%)$. Pada katarak pediatrik traumatik, trauma non perforans didapatkan pada 10 penderita $(66,7 \%)$ dan trauma perforans didapatkan pada 5 penderita $(33,3 \%)$. Pada kelompok katarak pediatrik non traumatik, penyebab terbanyak adalah idiopatik yaitu sebanyak 25 penderita $(80,6 \%)$, diikuti oleh infeksi maternal akibat rubella sebanyak 4 penderita $(12,9 \%)$, herediter pada 1 penderita $(3,2 \%)$, dan 1 penderita $(3,2 \%)$ berhubungan dengan anterior dysgenesis syndrome seperti peter's anomaly. Pada katarak traumatik semuanya ditemukan pada satu mata, sedangkan katarak non traumatik sebagian besar terjadi pada dua mata (71\%)

Onset terjadinya katarak pada kelompok traumatik lebih banyak (73,3\%) ditemukan pada usia yang lebih tua (6-10 tahun) dibandingkan katarak non traumatik yang banyak ditemukan sejak lahir (51,6\%). Usia terbanyak kelompok traumatik pada saat datang ke poliklinik dan dilakukan operasi adalah usia >6-10 tahun, sedangkan pada katarak non traumatik tindakan operasi banyak dilakukan pada usia 1-10 tahun. Gambaran ini secara tidak langsung menunjukkan bahwa pada katarak traumatik orang tua pasien lebih cepat memutuskan untuk dilakukan tindakan operasi.

Tabel 1. Gambaran klinis dan terapi katarak pediatrik traumatik dan non traumatik

\begin{tabular}{|c|c|c|c|}
\hline \multirow[t]{2}{*}{ Karakteristik } & \multirow[t]{2}{*}{ Parameter } & \multicolumn{2}{|c|}{ Jumlah (\%) } \\
\hline & & Traumatik & Non-traumatik \\
\hline \multirow[t]{8}{*}{ Onset } & 0 & & $16(51,6 \%)$ \\
\hline & 1-3 bulan & & $2(6,5 \%)$ \\
\hline & 4-6 bulan & & $3(9,7 \%)$ \\
\hline & $7-12$ bulan & & $3(9,7 \%)$ \\
\hline & 1-2 tahun & & $2(6,5 \%)$ \\
\hline & $2-6$ & $1(6,7 \%)$ & $4(12,9 \%)$ \\
\hline & $6-10$ & $11(73,3 \%)$ & $1(3,2 \%)$ \\
\hline & $>10$ & $3(20 \%)$ & \\
\hline \multirow[t]{5}{*}{ Usia saat operasi } & $0-0,5$ & & $3(9,7 \%)$ \\
\hline & $0,5-1$ & & $2(6,4 \%)$ \\
\hline & $1-6$ & $1(6,7 \%)$ & $12(38,7 \%)$ \\
\hline & $6-10$ & $11(73,3 \%)$ & $10(32,2 \%)$ \\
\hline & $>10$ & $3(20 \%)$ & $4(12,9 \%)$ \\
\hline \multirow[t]{2}{*}{ Lokasi } & Unilateral & $15(100 \%)$ & $9(29 \%)$ \\
\hline & Bilateral & & $22(71 \%)$ \\
\hline
\end{tabular}

Komplikasi pre operasi terbanyak kelompok traumatik adalah ruptur kapsul anterior lensa yang didapatkan pada 6 mata (40\%), kekeruhan vitreous sebanyak 4 mata 
(26,6\%), dan lekoma adheren sebanyak 3 mata (20\%) sesuai dengan akibat trauma. Pada kelompok non traumatik, komplikasi pre operasi terbanyak adalah nistagmus sebanyak 15 mata (34,9\%), dan strabismus sebanyak 9 mata $(20,9 \%)$.

Jenis operasi yang terbanyak pada kelompok katarak pediatrik traumatik adalah Extra Capsular Cataract Extraction (ECCE)+Intraocular Lens $(\mathrm{IOL})+$ iridektomi perifer sebanyak 9 mata (60\%). Teknik operasi ECCE+IOL+iridektomi perifer juga merupakan teknik operasi yang paling banyak dilakukan pada kelompok non traumatik, yaitu sebanyak 23 mata $(53,4 \%)$.

\section{Tabel 2. Distribusi operasi yang dilakukan}

\begin{tabular}{lccr}
\hline & Traumatik & Non Traumatik & \multicolumn{1}{c}{ Total } \\
\hline ECCE + IOL + IP & $9(60 \%)$ & $23(53,4 \%)$ & $32(55,2 \%)$ \\
ECCE + IOL + IP + KP & $4(26,7 \%)$ & $16(37,2 \%)$ & $20(34,5 \%)$ \\
ECCE + IOL + IP + KP + VA & $2(13,3 \%)$ & $4(9,3 \%)$ & $6(10,3 \%)$ \\
Total & $15(100 \%)$ & $43(100 \%)$ & $58(100 \%)$ \\
\hline
\end{tabular}

Keterangan: ECCE : Extra Capsular Cataract Extraction, IOL : Intraocular Lens, IP : iridektomi perifer, KP : kapsulotomi posterior, VA : vitrektomi anterior.

\section{Hasil Terapi}

Pada kelompok traumatik, visus pre operasi terbanyak adalah $1 / 300$, yaitu sebesar 7 mata $(46,7 \%)$. Pada kelompok non traumatik, visus pre operasi terbanyak adalah persepsi cahaya proyeksi baik sebanyak 15 mata (34,9\%); visus fiksasi cahaya pada 13 mata $(30,2 \%)$, dan visus $1 / 300$ pada 6 mata (14\%). Visus pasca operasi kelompok traumatik sebagian besar $>6 / 18$, yaitu pada 10 mata $(66,7 \%)$. Pada kelompok non traumatik sebagian besar visus pasca operasi adalah 1/60-3/60, yaitu sebanyak 13 mata $(30,2 \%)$. Perbaikan visus yang secara klinis lebih signifikan lebih banyak ditemukan pada katarak traumatik.

Tabel 3. Perbaikan visus sesudah operasi

\begin{tabular}{lllll}
\hline \multirow{2}{*}{ Visus } & \multicolumn{3}{c}{ Traumatik } & \multicolumn{2}{c}{ Non Traumatik } \\
\cline { 2 - 5 } & Pre & Post & Pre & Post \\
\hline Fiksasi cahaya & & & $13(30,2)$ & $4(9,3)$ \\
Fiksasi objek & & & $3(7)$ & $7(16,3)$ \\
LP good projection & $5(33,3)$ & & $15(34,9)$ & \\
LP bad projection & $1(6,7)$ & & $6(14)$ & $5(11,6)$ \\
$1 / 300$ & $7(46,7)$ & & $3(7)$ & $13(30,2)$ \\
$1 / 60-3 / 60$ & $2(133)$ & $2(13,3)$ & $3(7)$ & $7(16,3)$ \\
$4 / 60-6 / 18$ & & $3(20)$ & $7(16,3)$ \\
$>6 / 18$ & & $10(66,7)$ & & \\
\hline
\end{tabular}

Pengamatan pada data follow up menunjukkan waktu follow up terbanyak dilakukan pada 2-6 bulan, yaitu sebanyak 19 mata (32,7\%). Selanjutnya diikuti oleh follow up pada rentang waktu $>12$ bulan sebanyak 15 mata $(25,8 \%), \leq 1$ bulan sebanyak 14 mata $(24,1 \%)$, dan $7-12$ bulan didapatkan pada 10 mata $(17,2 \%)$.

Tabel 4 menunjukkan komplikasi yang terbanyak didapatkan pasca operasi. Pada kelompok traumatik, 12 dari 15 mata mengalami komplikasi. Sebanyak 10 mata (66,7\%) mengalami Posterior Capsular Opacification (PCO), diikuti oleh komplikasi berupa pupil irregular pada 7 mata $(46,6 \%)$. Untuk kelompok non traumatik, komplikasi pasca operasi didapatkan pada 38 dari 43 mata. Komplikasi terbanyak pada kelompok ini adalah ambliopia, yaitu sebanyak 30 mata $(69,7 \%)$ dan PCO sebesar 26 mata $(60,4 \%)$.

Tabel 4. Distribusi komplikasi pasca operasi

\begin{tabular}{lcc}
\hline & Traumatik & Non Traumatik \\
\hline PCO & $10(66,7 \%)$ & $26(60,4 \%)$ \\
Ambliopia & $0(0 \%)$ & $30(69,7 \%)$ \\
Inflamasi & $3(20 \%)$ & $10(23,2 \%)$ \\
Pupil irregular & $7(46,6 \%)$ & $16(37,2 \%)$ \\
Desenterasi IOL & $1(6,7 \%)$ & $5(11,6 \%)$ \\
Sinekia posterior & $0(0 \%)$ & $9(20,9 \%)$ \\
\hline
\end{tabular}

Untuk mengetahui hubungan antara visus pasca operasi dengan usia saat dilakukannya tindakan operasi, dan tingginya angka kejadian PCO dengan jenis operasi yang dilakukan, dilakukan analisa korelasi. Hasil menunjukkan hubungan positif yang kuat dan bermakna antara semakin terlambatnya usia operasi dengan buruknya visus pasca operasi $(r=0,707 ; p=0,000)$. Jenis operasi dengan kejadian PCO tidak menunjukkan korelasi yang bermakna ( $r=0,053$; $\mathrm{p}=0,691)$.

\section{DISKUSI}

\section{Karakteristik Klinis Katarak Pediatrik}

Hasil penelitian yang diperoleh dari data rekam medis mendapatkan 108 penderita yang didiagnosa menderita katarak pediatrik, akan tetapi yang memenuhi kriteria inklusi hanya berjumlah 46 penderita dengan 58 mata. Hal ini disebabkan karena pada penelitian ini, banyak penderita dengan diagnosa katarak pediatrik yang telah ditegakkan tidak kembali ke poliklinik untuk dilakukan penatalaksanaan lebih lanjut karena alasan ketiadaan biaya, dan rendahnya pengetahuan orang tua mengenai keadaan anak.

Hasil pengumpulan data menunjukkan bahwa jumlah penderita katarak pediatrik dengan jenis kelamin laki-laki adalah 2 kali lipat lebih besar daripada perempuan. Hasil penelitian ini sama dengan hasil penelitian yang didapat sebelumnya oleh Johar et al dan Perucho-Martinez et al. Meskipun secara umum tidak ada predileksi jenis kelamin tertentu terhadap kejadian katarak pediatrik, akan tetapi prevalensi tersebut disebabkan karena adanya ekspektasi sosial terhadap peran anak laki-laki dalam masyarakat dibandingkan dengan alasan biologis $(1,9,10)$.

Penyebab utama dari katarak pediatrik yang didapatkan pada penelitian ini adalah non traumatik $(67,4 \%)$. Hasil ini serupa dengan yang didapat oleh Johar et al, Adhikari et al, dan Perucho-Martinez et al. Seperti telah disebutkan sebelumnya, penyebab non trauma terdiri dari beberapa penyebab antara lain herediter, katarak sekunder, 
metabolik, infeksi maternal akibat TORCH, maupun idiopatik $(1,9,10)$

Penyebab terbanyak dari kelompok traumatik adalah trauma non perforans (66,7\%). Penelitian oleh Johar et al, Reddy et al, Lim et al mendapatkan hasil yang sama, akan tetapi terdapat sedikit perbedaan dengan literatur serta penelitian sebelumnya oleh Perucho-Martinez et al dan Adhikari et al yang menyebutkan bahwa penyebab utama dari kelompok traumatik adalah trauma perforans. Hasil penelitian ini kemungkinan disebabkan kurang mengertinya orang tua mengenai dampak jangka panjang yang diakibatkan oleh katarak traumatika terhadap penglihatan anak. Saat anak mereka menjalani operasi akibat trauma perforans yang diderita mereka menganggap hal tersebut sebagai pengalaman traumatik bagi anak, sehingga orang tua tidak membawa anaknya kembali untuk menjalani operasi katarak (1,9-12).

Pada kelompok non traumatik penyebab terbanyak adalah idiopatik (80,6\%). Hasil penelitian yang serupa juga didapatkan oleh Johar et al, Reddy et al, dan Lim et al. Literatur menyebutkan bahwa idiopatik adalah penyebab terbanyak pada katarak pediatrik non traumatik. Penyebab katarak dikatakan idiopatik jika tidak didapatkan faktor penyebab katarak yang lain. Lim et al dan Martinez et al menyatakan terdapat kemungkinan bahwa penyebab idiopatik pada katarak sebenarnya diturunkan (herediter) tetapi tidak diketahui akibat tidak adanya keluarga yang menunjukkan penyakit yang sama. Untuk mengetahuinya dapat dilakukan pemeriksaan genetik terhadap keluarga penderita, akan tetapi hal tersebut tidak selalu dapat dilakukan karena bergantung pada keadaan sosioekonomi penderita (1,9-12).

Usia terbanyak saat penderita datang ke poli mata dan kemudian dilakukan tindakan operasi pada kelompok traumatik adalah usia $>6-10$ tahun $(73,3 \%)$, dengan usia onset katarak terbanyak pada usia >6-10 tahun. Hasil penelitian sebelumnya oleh Martinez et al dan Adhikari et al (2007) mendapatkan hasil yang serupa. Dari data tersebut di atas terlihat bahwa pada katarak traumatik, orang tua akan cenderung lebih cepat untuk membawa anak ke pusat kesehatan sehingga dapat terdiagnosa dan memperoleh tata laksana lebih cepat (early). Waktu diagnosa dikatakan awal (early) jika diagnosa tersebut dibuat kurang dari 4-6 minggu setelah onset katarak $(1,9)$.

Pada kelompok non traumatik, usia terbanyak saat penderita datang ke poli mata dan menjalani operasi katarak adalah $>1-6$ tahun $(73,3 \%)$, sementara onset katarak terbanyak adalah sejak lahir $(51,6 \%)$. Hasil ini pun serupa dengan penelitian oleh Mwende et al dan Adhikari et al $(4,9)$. Pada kelompok ini tampak adanya kemungkinan keterlambatan diagnosa mengingat pada sebagian besar kasus, anak baru dibawa ke pusat kesehatan saat berusia >1-6 tahun. Keterlambatan diagnosa dan terapi pada kelompok non traumatik juga didapatkan pada penelitian oleh Mwende et al di Tanzania. Adhikari et al dan Mwende et al mengatakan bahwa latar belakang yang mungkin menyebabkan hal ini adalah karena kurangnya pengetahuan dan kewaspadaan orang tua akan keadaan anak dan dampak serius yang ditimbulkan, dan terbatasnya akses ke pusat kesehatan terutama pada penduduk di daerah terpencil $(4,9)$. Keterlambatan diagnosa akan berakibat keterlambatan dalam mendapatkan tata laksana yang tepat dan dapat berakhir dengan kebutaan pada anak $(1,4,9)$.
Berdasarkan lokasi kataraknya, pada kelompok traumatik seluruh penderita hanya mengalami katarak pada 1 mata saja (unilateral), Hasil yang kami dapatkan sesuai dengan literatur serta beberapa penelitian yang telah dilakukan sebelumnya. Dikatakan dalam literatur bahwa trauma merupakan salah satu penyebab utama katarak unilateral pada anak (1,3,9-13). Untuk kelompok non traumatik sebagian besar katarak adalah bilateral. Disebutkan dalam literatur serta beberapa penelitian sebelumnya bahwa herediter merupakan penyebab tersering kedua katarak pediatrik non traumatik setelah idiopatik, dimana penurunannya bersifat autosomal dominan, bilateral, dan dapat asimetris. Penegakan penyebab herediter ini tidak mudah dan perlu dilakukan anamnesa secara seksama mengenai riwayat penyakit yang sama pada orang tua atau anggota keluarga lain yang mungkin asimptomatis. Lim et al dan Perucho-Martinez et al telah menyatakan sebelumnya bahwa kemungkinan penyebab idiopatik pada katarak sebenarnya adalah herediter. Hal inilah yang mungkin berperan pada hasil penelitian yang kami dapatkan (1,3,9-13).

Tajam penglihatan/visus pre operasi yang terbanyak didapatkan pada kedua kelompok katarak pediatrik tidak menunjukkan banyak perbedaan. Visus $1 / 300$ adalah yang terbanyak didapatkan pada kelompok traumatik. Pemeriksaan pada kelompok ini tidak mendapatkan visus fiksasi cahaya maupun fiksasi objek karena semua penderita pada kelompok ini memiliki onset usia 48 bulan (4 tahun), sehingga telah memungkinkan untuk bekerjasama dengan pemeriksa dan dapat dilakukan pemeriksaan tajam penglihatan dengan baik $(8,14,15)$.

\section{Penatalaksanaan}

Operasi yang paling banyak dilakukan baik pada kelompok traumatik maupun non traumatik adalah ECCE+IOL +iridektomi perifer. Dalam literatur dikatakan bahwa beberapa teknik operasi yang umumnya dilakukan pada katarak pediatrik adalah ECCE dengan atau tanpa IOL, yang dapat dikombinasi dengan tindakan seperti vitrektomi anterior, kapsulotomi posterior. Tindakan tersebut bertujuan untuk mencegah timbulnya kekeruhan ulang pada aksis visual atau PCO. Akan tetapi tidak ada petunjuk yang jelas mengenai kapan teknik-teknik tersebut dilakukan, serta pada usia berapa vitrektomi anterior dilakukan. Pada tahun 1990, Dahan dan Salmenson merekomendasikan perlunya dilakukan kapsulotomi posterior dan vitrektomi anterior pada anak usia kurang dari 8 tahun. Mengingat penelitian kami merupakan penelitian deskriptif maka data yang kami kumpulkan akan sangat berpengaruh pada hasil penelitian. Sedikitnya prosentase tindakan kapsulotomi posterior dan vitrektomi anterior yang dilakukan pada hasil penelitian kami kemungkinan disebabkan akibat kurang lengkapnya pencatatan tindakan operasi yang dilakukan, sehingga jumlah tindakan tersebut kemungkinan lebih besar dari data yang tercatat pada rekam medis $(7,16)$.

\section{Hasil Operasi}

Tajam penglihatan/visus pre operasi pada kedua kelompok katarak pediatrik tidak banyak berbeda, akan tetapi pada visus pasca operasi didapatkan perbedaan yang besar. Pada kelompok traumatik, mayoritas visus penderita mengalami peningkatan hingga mencapai $>6 / 18$, Dalam literatur dikatakan bahwa visus anak mengalami perkembangan cepat pada 6 bulan pertama, dan akan 
mencapai tajam penglihatan sempurna pada usia 6 tahun. Gangguan yang didapatkan pada masa kritis ini akan berdampak pada buruknya penglihatan bahkan kebutaan pada anak. Pada kelompok traumatik, onset katarak sebagian besar didapatkan pada usia $>6$ tahun, dimana pada usia ini sudah didapatkan perkembangan tajam penglihatan yang optimal. Pada kelompok ini, hanya didapatkan 2 mata (13,3\%) dengan visus $1 / 60-3 / 60$. Hal ini dapat terjadi jika didapatkan komplikasi akibat trauma yang berat, seperti kekeruhan vitreous ataupun peningkatan tekanan intra okuler (TIO) yang sudah berlangsung beberapa lama. Jika tidak didapatkan komplikasi akibat trauma yang berat, maka akan didapatkan visus pasca operasi yang baik $(13,17)$.

Pada kelompok non traumatik sebagian besar penderita hanya mencapai visus $1 / 60-3 / 60$ pasca operasi, atau tergolong dalam keadaan low vision. Dari data yang didapat, banyak dari penderita pada kelompok ini yang terlambat dibawa ke pusat kesehatan sementara mayoritas telah mengalami katarak sejak lahir. Sementara keterlambatan ini tidak didapatkan pada kelompok traumatik. Keterlambatan untuk menjalani operasi inilah yang diduga menjadi penyebab buruknya tajam penglihatan anak pasca operasi. Keadaan ini sesuai dengan yang didapatkan pada hasil analisa korelasi Spearman yang telah dilakukan, dimana terdapat hubungan yang signifikan terhadap semakin terlambatnya usia penderita saat dilakukan operasi dengan buruknya visus pasca operasi ( $p$ value $=0,000$ $(13,17)$.

Dalam hal komplikasi yang terjadi, secara keseluruhan komplikasi pre operasi yang tersering adalah nistagmus, dan komplikasi pasca operasi yang paling banyak didapatkan adalah PCO dan ambliopia. Hasil yang kami dapatkan sesuai dengan literatur dan beberapa penelitian sebelumnya oleh Adhikari et al, Johar et al, dan Lim et al yang menyebutkan bahwa komplikasi tersering pasca operasi adalah ambliopia dan PCO (9-11). Nistagmus dan strabismus yang terjadi sebelum dilakukannya operasi

\section{DAFTAR PUSTAKA}

1. Perucho-Martínez S, De-la-Cruz-Bertolo J, and TejadaPalacios P. Pediatric Cataracts: Epidemiology and Diagnosis, Retrospective Review of 79 Cases. Archivos de la Sociedad Espanola de Oftalmologia. 2007; 82(1): 37-42.

2. Iqbal M, Jan S, Khan MN, Iqbal A, and Mohammod S. Pediatrics Intraocular Lens Implantation Complications and Visual Outcome. Pakistan Journal of Medical Research. 2004; 43 (3): 108-112.

3. Khandekar R, Sudhan A, Jain B K, Shrivastav K and Sachan R. Pediatric Cataract and Surgery Outcomes in Central India: A Hospital Based Study. Indian Journal of Medical Sciences. 2007; 61(1):15-22.

4. Mwende J, Bronsard A, Mosha M, Bowman R, Geneau $\mathrm{R}$ and Courtright P. Delay in Presentation to Hospital for Surgery for Congenital and Developmental Cataract in Tanzania. The British Journal of Ophthalmology. 2005; 8 (11): 1478-1482.

5. Casaer P, Casteels I, and Foets B. Surgical Treatment Outcomes of Congenital and Juvenile Cataracts. katarak merupakan indikator telah terjadi ambliopia yang berat dan sulit untuk diterapi. Penderita dengan keadaan ini akan sulit untuk mendapatkan tajam penglihatan yang baik pasca operasi $(9,18-20)$.

Follow up yang paling banyak didapatkan pada penelitian ini adalah 2-6 bulan. Dalam literatur disebutkan bahwa follow up jangka panjang sangat diperlukan untuk mendeteksi dan mengatasi komplikasi pasca operasi seperti PCO, dan mengevaluasi ada tidaknya ambliopia. Posterior capsular opacity dapat timbul segera setelah operasi atau dalam jangka waktu 12-18 bulan pasca operasi. Masih banyaknya penderita yang hanya melakukan follow up $\leq 1$ tahun memerlukan perhatian dari klinisi untuk memberikan keterangan pada orang tua mengenai penyakit yang diderita anak secara jelas $(16,21)$.

Hasil ini menunjukkan tidak adanya hubungan antara tidak dilakukannya tindakan kapsulotomi posterior maupun vitrektomi anterior dengan tingginya angka kejadian PCO pada penelitian kami. Literatur menyebutkan bahwa salah satu usaha untuk mengurangi resiko terjadinya PCO adalah dengan melakukan operasi katarak yang dikombinasi dengan kapsulotomi posterior atau vitrektomi anterior. Ketidaksesuaian hasil yang kami dapat dengan literatur dapat disebabkan karena masih banyaknya penderita yang melakukan follow up hanya dalam waktu kurang dari 12 bulan, sementara pada literatur disebutkan bahwa PCO dapat terjadi segera atau dalam waktu 12-18 bulan pasca operasi $(18,19,21,22)$.

Hasil penelitian ini memberikan gambaran klinis penderita katarak pediatrik lebih banyak pada non traumatik dengan lokasi bilateral. Hasil juga menunjukkan bahwa visus pasca operasi dipengaruhi oleh kecepatan diagnosis dan tindakan operasi namun tidak berhubungan dengan jenis operasi. Hal ini mengindikasi bahwa diagnosis dini terutama pada katarak non traumatik dengan melibatkan orang tua memegang peranan penting pada prognosis pasca operasi.

Bulletin de la Societe Belge d'Ophtalmologie. 2005; 297:47-57.

6. Karimian F, Ali JM, and Jafarinasab MR. Pediatric Cataract Surgery. Iranian Journal of Ophthalmic Research. 2007; 2 (2): 146-153.

7. Wilson ME, Pandey SK, and Thakur J. Paediatric Cataract Blindness in the Developing World: Surgical Techniques and Intraocular Lenses in The New Millennium. The British Journal of Ophthalmology. 2003; 87: 14-19.

8. Pandey SK and Wilson ME. Etiology and Morphology of Pediatric Cataract. In: Wilson ME (Ed). Pediatric Cataract Surgery: Techniques, Complications, and Management. Philadelphia: Lippincot Williams \& Wilkins; 2005; p. 6-12.

9. Adhikari S, Badhu BP, Bhatta NK, Jha CB, Baral N and Kumari N. Etiology and Clinical Profile of Pediatric Cataract in a Tertiary Care Centre of Eastern Nepal. Journal of the Nepal Medical Association. 2007; 46 (167): 94-98.

10. Johar SR, Savalia NK, Vasavada AR and Gupta PD. 
Epidemiology Based Etiological Study of Pediatric Cataract in Western India. Indian Journal of Medical Sciences. 2004; 58(3): 115-121.

11. Lim Z, Rubab Z, Chan Y, and Levin AV. Pediatric Cataracy: The Toronto Experience-Etiology. American Journal of Ophthalmology. 2010; 149(6): 887-892.

12. Reddy AK, Ray R, and Yen KG. Surgical Intervention for Traumatic Cataracts in Children: Epidemiology, Complications, and Outcomes. Journal of the American Association for Pediatric Ophthalmology and Strabismus. 2009; 13(2): 170-174.

13. Lewis TL and Maurer D. Multiple Sensitive Periods in Human Visual Development: Evidence from Visually Deprived Children. Developmental Psychobiology. 2005; 46(3): 163-183.

14. American Academy of Pediatric. Eye Examination in Infants, Children, and Young Adults by Pediatricians. Pediatrics. 2003; 111(4): 902-907.

15. Dahan E. Pediatric Cataract Surgery. In: Yanoff M. Ophthalmology, 3rd edition. China: Elsevier Inc.; 2009: p. 479-490.

16. Petric I and Lonear VL. Surgical Technique and
Postoperative Complications in Pediatric Cataract Surgery: Retrospective Analysis of 21 Cases. Croatian Medical Journal. 2004; 45(3): 287-291.

17. Wright KW. Lens Abnormalities. In: Wright KW. Pediatric Ophthalmology and Strabismus. New York: Springer-Verlag; 2003; p. 450-473.

18. Gimbel HV and DeBroof B. Surgical Management of Pediatric Cataract. In: Steinert RF (Ed). Cataract Surgery: Technique, Complications, Management 2nd edition. Philadelphia: Saunders; 2004: p.273-277.

19. Lambert SR. Cataract and Persistent Hyperplastic Primary Vitreous (PHPV). In: Taylor D (Ed). Pediatric Ophthalmology and Strabismus, 3rd edition. China; Elsevier-Saunders; 2005: p. 441-445.

20. American Academy Association. Pediatric Ophthalmology. San Fransisco: American Academy of Ophthalmology; 2010-2011; p. 246-260.

21. Pajic B and Muller J. Management of Pediatric Cataract and Novel Surgery Procedures. In: Garg A (Ed). Surgical and Medical Management of Pediatric Ophthalmology 1st volume. New Delhi; Jaypee Brothers Medical Publishers; 2007: p. 235-246. 